\title{
PENGARUH MATERIAL LANSEKAP TERHADAP PERUBAHAN IKLIM MIKRO DI KOTA TROPIS LEMBAB DENGAN STUDI KASUS DI KAWASAN PANTAI KOTA MANADO
}

\author{
Zahra \\ Mahasiswa Program Studi Arsitektur (S2), Pascasarjana Universitas Sam Ratulangi, Manado \\ e-mail: zahra1112@student.unsrat.ac.id

\begin{abstract}
Sangkertadi
Dosen Program Studi Arsitektur (S2), Pascasarjana Universitas Sam Ratulangi, Manado e-mail: sangkertadi@unsrat.ac.id
\end{abstract}

\section{Veronica Kumurur} \\ Dosen Program Studi Arsitektur (S2), Pascasarjana Universitas Sam Ratulangi, Manado \\ veronicakumurur@unsrat.ac.id
}

\begin{abstract}
ABSTRAK
Tujuan studi untuk mengetahui seberapa besar pengaruh material lansekap terhadap perubahan iklim mikro di lingkungan beriklim tropis lembab. Material lansekap memiliki sifat termofisis tertentu yang dapat mempengaruhi perubahan iklim mikro. Variabel iklim mikro dalam studi ini dibatasi hanya suhu permukaan, dan suhu udara. Sasaran material lansekap adalah bata, tanah keras, pavingstone, pepohonan, dan air kolam taman. Metode penelitian adalah analisis deskriptif kuantitatif. Melalui studi ini dilakukan pengukuran sifat termofisis pada material lokal yaitu bata dan paving-block, dengan menggunakan kalorimeter dan termokopel. Juga di lakukan pengukuran iklim mikro di kawasan jasa di pantai kota Manado, yaitu radiasi matahari, suhu udara, dan suhu permukaan bahan. Kemudian dilakukan perhitungan menggunakan program komputer HEAT2 untuk alat bantu analisis perubahan suhu permukaan berbagai bahan lansekap. Hasilnya menunjukkan bahwa saat tengah hari, pepohonan dapat mereduksi radiasi matahari di naungannya sampai 80 \%. Pada saat yang sama, apabila berada di bawah terik matahari, material bata, paving dan tanah keras, dapat menyebabkan suhu permukaan yang bisa mencapai $50^{\circ} \mathrm{C}$. Suhu permukaan air kolam taman juga dapat mencapai $50{ }^{\circ} \mathrm{C}$, namun di kedalaman $50 \mathrm{~cm}$ lebih dingin menjadi $25^{\circ} \mathrm{C}$. Air berpotensi sebagai pendingin lingkungan, apabila terjadi pencampuran air dasar kolam dan permukaannya.
\end{abstract}

Kata kunci : lansekap, material, suhu permukaan, tropis lembab, 


\section{ABSTRACT}

The purpose of the study is to know the influence of landscape materials on changes of microclimate in a humid tropical sites due to thermophysical properties of materials. Microclimate variables in this study were limited to surface and air temperature. The object materials were bricks, hard-soil, paving-blocks, trees, and garden-pond water. The research method was descriptive quantitative. Measurement of thermophysical properties of local materials, namely brick and pavingstone, were carried out using calorimeter and thermocouples. Measurements of solar radiation, air and surface temperatures were also carried out in a commercial area on the coast of Manado city. Then calculations were realised by using HEAT2 computer program as tool to evaluate surface temperature of various landscape materials. The results show that at midday, trees can reduce solar radiation in their shade by up to $80 \%$. At the same time, when under the sun, brick, paving and hard soil materials, result surface temperatures by up to $50^{\circ} \mathrm{C}$. The surface temperature of garden pond water may reach $50{ }^{\circ} \mathrm{C}$, but at a depth $50 \mathrm{~cm}$ it may lower to $25^{\circ} \mathrm{C}$. Water pond-garden has potentiallity to cool the environment, if there is a mixing of the bottom and its surface..

Keywords : tropical humid, landscape, material, surface temperature 


\section{PENDAHULUAN}

Pada umumnya manusia yang beraktifitas di ruang luar merasa nyaman secara fisiologis apabila berada di lingkungan dengan suhu yang tidak terlalu panas dan tidak juga terlalu dingin, apalagi ditambah hembusan angin sejuk. Namun sengatan panas matahari yang dapat sangat panas di siang hari, menyebabkan rasa tidak nyaman secara termal, sehingga manusia berupaya mencari perlindungan dibawah naungan, misalnya dibawah pohon atau di bawah suatu peneduhan lainnya. Dalam hal ini selain faktor iklim dari atmosfir, morfologi dan anatomi fisik dari arsitektur ruang luar juga berperan sebagai penyebab bervariasinya tingkat nyamantermal bagi manusia yang berkegiatan, baik pada saat malam maupun siang hari. Dalam hal ini sifat fisikalis dari bahan permukaan lansekap dapat menyebabkan perubahan iklim mikro. Suhu permukaan material yang terkena sengatan matahari di siang hari, dapat menyebabkan radiasi panas material yang juga menambah beban panas ruang luar. Variabel iklim mikro yang paling berpengaruh terhadap skala kenyamanan-termal di ruang luar, adalah suhu radiasi dan suhu udara serta angin (Givoni, 1998; Sangkertadi, 2013; Sangkertadi \& Syafriny, 2016).

Morfologi lansekap yang tersusun atas berbagai jenis material diketahui mempengaruhi perubahan iklim mikro, khususnya suhu lingkungan (Thani dkk, 2017). Namun demikian, sifat termofisis material lansekap merupakan bagian yang tidak terpisahkan dari karakteristik morfologi. Bahkan permukaan air juga mempengaruhi iklim mikro (Lesi, 2017). Sifat termofisis bahan akan mempengaruhi suhu permukaannya dan bersifat radiatif, saat menerima penetrasi radiasi matahari di ruang luar (Szokolay, 2010, Zold \& Szokolay, 1997). Sifat morfologi fisis penghijauan juga berpengaruh signifikan terhadap filtrasi radiasi panas matahari (Shahidan dkk, 2007). Apabila diketahui karakteristik termofisis material, maka memudahkan untuk melakukan optimalisasi desain arsitektur lansekap untuk menghasilkan iklim mikro yang nyaman bagi pemakainya (Choi, dkk 2021). Studi studi terdahulu tersebut kebanyakan menggunakan referensi material yang sumber data sifat fisisnya berasal dari literatur terbitan Eropa dan Amerika. Sedangkan dalam kasus penelitian ini, menggunakan material lokal, yang diukur sifat termofisisnya terlebih dahulu, kemudian dilihat dampaknya terhadap respon termal lingkungan. Jadi dugaan bahwa material lokal memiliki sifat termofisis yang berbeda dengan yang ada di literatur, karena itu juga akan menyebabkan respon termal yang berbada dengan studi sebelumnya. 
Secara lebih spesifik, studi ini bertujuan untuk mendapatkan informasi lebih mendalam mengenai besarnya variabel iklim mikro akibat penerapan berbagai jenis material lansekap, yang terdiri atas jenis perkerasan permukaan yang ada di lokasi penelitian (batu bata, paving, tanah), air dan pepohonan. Adapun variabel iklim mikro yang dimaksud meliputi suhu permukaan bahan, suhu udara, dan penetrasi radiasi matahari. Sebagai studi kasus lokasi adalah pada kawasan pantai area komersial Mega Mas di Kota Manado. Pada kawasan tersebut, formasi lansekapnya terdiri atas material perkerasan, maupun pepohonan, dan terdapat pula kolam air taman (Gambar.1). Saat siang hari di ruang luarnya nampak sunyi, mungkin karena faktor iklim mikro yang panas, namun saat malam hari banyak pengunjung beraktifitas di luar.
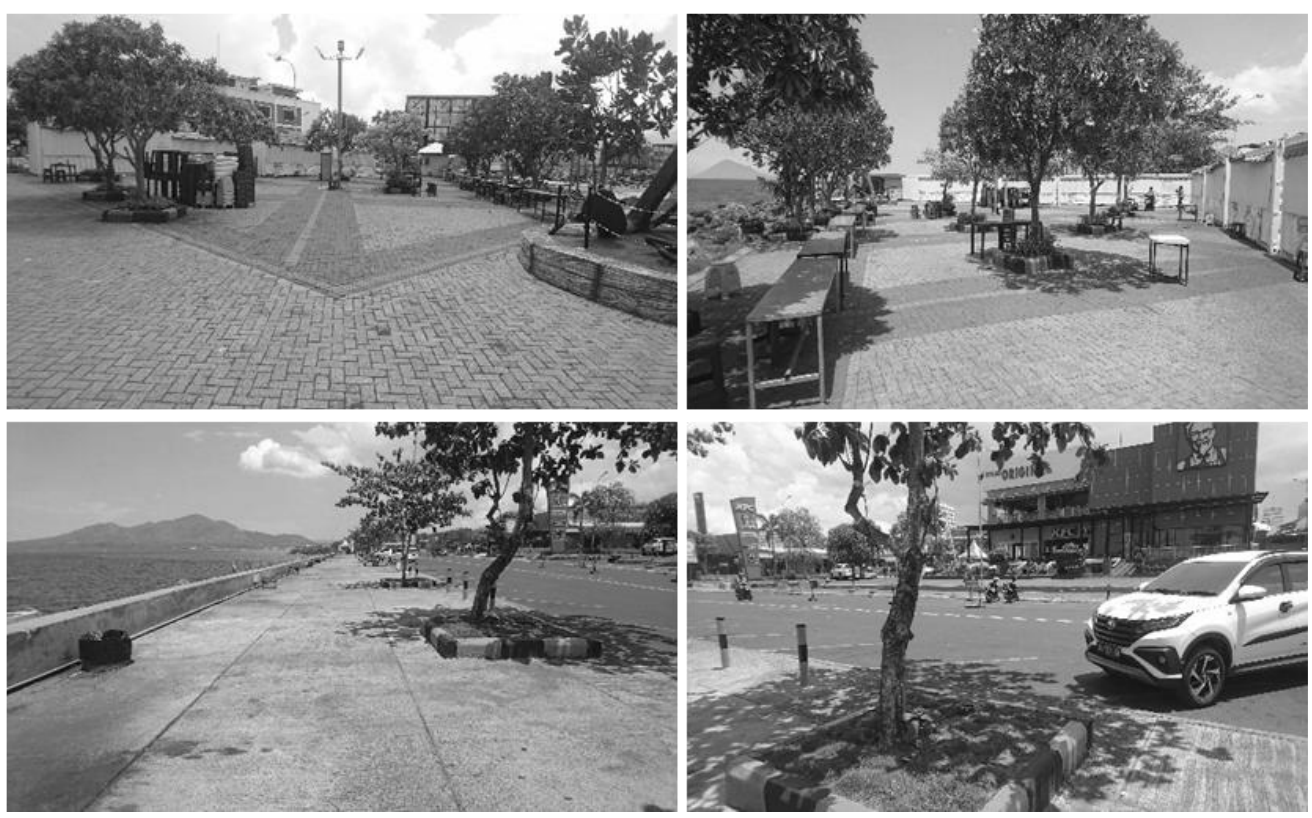

Gambar.1. Suasana arsitektur lansekap ruang luar di area komersial di pantai Kota Manado.

\section{TINJAUAN PUSTAKA}

Di iklim tropis, faktor besarnya energi radiasi matahari menjadi sumber utama penyebab panas lingkungan di ruang luar. Dari sejumlah literatur tentang fisika perpindahan panas dijelaskan bahwa energi panas dari radiasi matahari dan langit sebagian diserap oleh material lansekap, sebagian dipantulkan dan sebagian lagi diteruskan ke tanah (Szokolay, 2010; Zold \& Szokolay, 2007; ASHRAE, 2017). Kemudian setelah beberapa saat, material memancarkan panas radiasi ke lingkungan sekitarnya, dikarenakan

PAWON: Jurnal Arsitektur, Nomor 02 Volume V, Juli-Desember Tahun 2021, ISSN 2597-7636 
keterbatasan kapasitas material dalam menyimpan panas (Noerwasito, 2020). Dalam hal ini maka kapasitas kalor bahan dan sifat emissivitas bahan adalah dua parameter penting untuk mencegah emisi panas yang terlalu besar ke lingkungan sekitarnya. Selain itu sifat konduktifitas termal bahan juga mempengaruhi daya mampu suatu material untuk menyalurkan energi panas ke material lainnya, misalnya dari permukaan paving ke tanah.

Secara mendasar pengertian dari iklim mikro adalah kondisi iklim pada daerah dengan luasan atau fungsi yang terbatas, namun komponennya sebagian besar sama dengan pada kondisi iklim makro, yakni antara lain meliputi suhu udara, kelembaban, angin, serta penyinaran matahari. Pembahasan iklim mikro umumnya ditujukan untuk kepentingan studi tertentu seperti kawasan perkotaan, kawasan pedesaan, atau yang lainnya. (Lakitan, 2002; Karyati, 2019)

Karena dalam lingkup area yang terbatas maka perubahan iklim mikro dipengaruhi oleh unsur fisik yang ada di lingkungan area terbatas tersebut. Misalnya pada kawasan pusat perkotaan, maka pengaruh arsitektur kota atau lansekap kota akan sangat signifikan dalam proses perubahan unsur iklim mikro, misalnya perubahan suhu udara, kelembaban dan pergerakan angin (Gaitani dkk, 2011; lek dkk, 2014).

Dalam lingkup pengetahuan sains arsitektur sifat termofisis bahan yang paling utama dipertimbangkan meliputi kapasitas kalor, konduktifitas termal, emisivitas dan masa jenis (Szokolay, 2010, Noerwasito, 2020). Radiasi matahari yang menerpa bidang horisontal di daerah beriklim tropis, saat tengah hari dapat mencapai lebih dari $1000 \mathrm{~W} / \mathrm{m} 2$ (Lakitan, 2002 ). Panas ini dapat menyebabkan suhu permukaan lingkungan yang bisa mencapai $40{ }^{\circ} \mathrm{C}$ pada material perkerasan seperti beton (Takebayashi \& Kyogoku, 2018). Faktor warna material pun juga berpengaruh, karena berdampak pada sifat albedo, yang kemudian mempengaruhi mnilai emissivitas, dan pada akhirnya menyebabkan tingginya suhu radiasi atau suhu permukaan bahan (Lesi, 2017; Joo-Hwa \& Lay, 2006)

\section{METODE PENELITIAN}

Proses penelitian ini menerapkan metode deskripsi kuantitatif yang mencakup proses pengukuran, perhitungan praktis dan simulasi komputer. Secara skematik proses penelitian ditunjukkan melalui Gambar. 2. Lokasi pengukuran lapangan di kawasan pantai Mega Mas, Kota Manado (Gambar.1)

\subsection{Pengukuran Sifat bahan}

Bahan material yang dipilih untuk diukur sifat termofisis material dalam studi ini adalah batu bata, dan paving-block, yang merupakan produk 
tradisional lokal. Pengukuran laboratorium untuk mengetahui nilai kapasitas kalor (c) dengan satuan Joule $/ \mathrm{kg}^{\circ} \mathrm{C}$ dan konduktivitas termal dengan satuan $\mathrm{W} / \mathrm{m}^{0} \mathrm{C}$, serta massa jenis dalam satuan $\mathrm{kg} / \mathrm{m}^{3}$. Alat ukur yang di gunakan meliputi kalorimeter joule, termokopel, yang didukung dengan perangkat timbangan digital, jangka ukur, gelas ukur, termometer air raksa, serta infrared thermometer. Bahan lainnya yang juga menjadi bagian dari proses penelitian, seperti tanah dan air, menggunakan data umum (kapasitas kalor, konduktifiitas termal) yang sudah di sejumlah literatur.

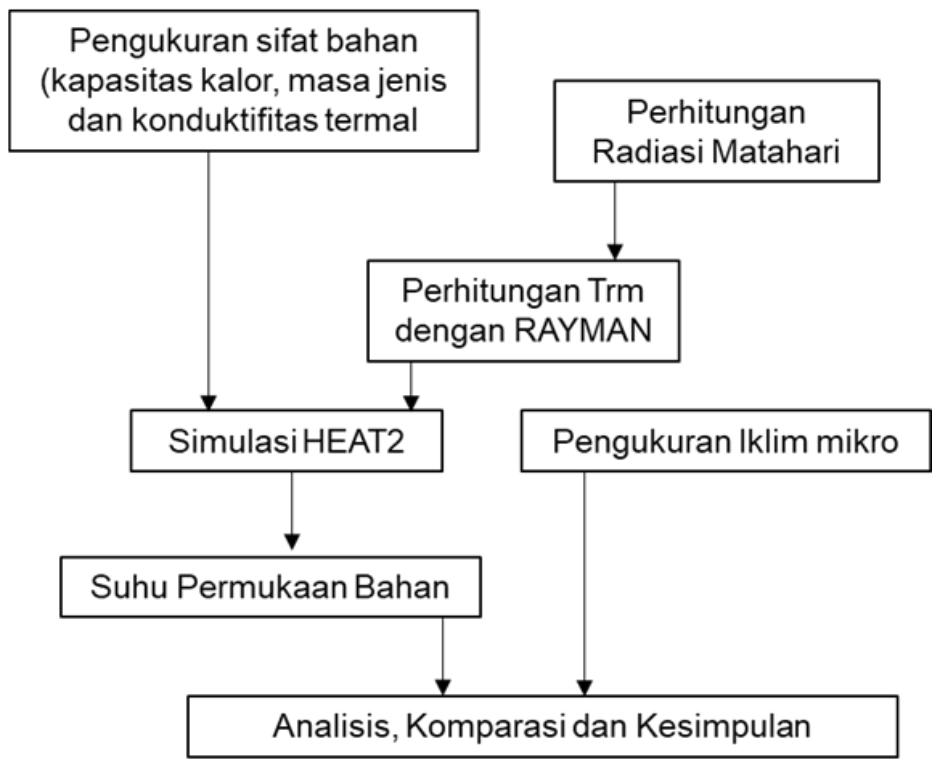

Gambar. 2. Diagram proses penelitian

\subsection{Pengukuran Iklim Lingkungan}

Pengukuran iklim lingkungan meliputi suhu udara, suhu permukaan bahan dan radiasi matahari. Dilakukan saat matahari tidak tertutup awan. Peralatan terdiri atas infra red thermometer (untuk mengukur suhu permukaan material), solar power meter (untuk mengukur radiasi matahari) dan thermometer digital (untuk mengukur suhu udara). Pengukuran suhu permukaan dan radiasi dilakukan pada titik yang terletak dibawah naungan pepohonan berdaun rapat, dan yang menghadap pada langit terbuka terkena sinar matahari langsung. Selain itu juga dilakukan pengukuran suhu permukaan air kolam taman, dan suhunya pada dasar kolam sedalam 50 $\mathrm{cm}$. Pengukuran suhu udara pada titik ketinggian kegiatan manusia yaitu 1.5 $\mathrm{m}$ dari permukaan bahan.

\subsection{Simulasi Komputasi dan Perhitungan Praktis}

Perhitungan simulasi perpindahan panas konduksi menggunakan program komputer HEAT2, yakni untuk mengetahui besarnya suhu 
permukaan bahan akibat penetrasi radiasi dari bagian atas, dimana pemodelan geometriknya sebagaimana pada gambar 3 dan 4 . Radiasi matahari dari atas, selanjutnya menyebabkan suhu radiasi yang menerpa material dimana terdapat lapisan udara diatasnya (lapisan udara tipis berperan sebagai suatu film conductance dalam mekanisme perpindahan panas konduksi).

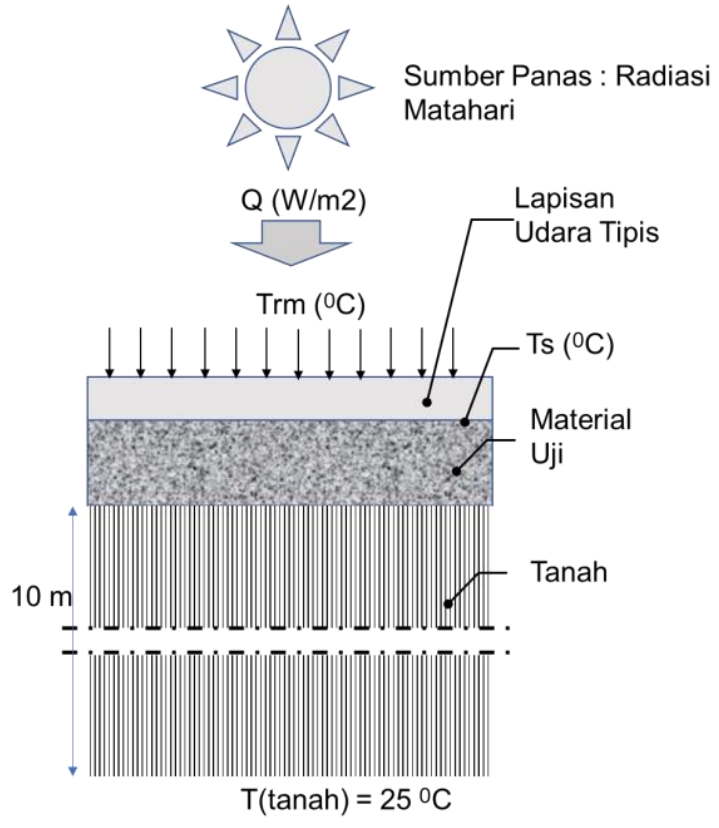

Gambar.3. Pemodelan sistim material untuk proses simulasi komputasional

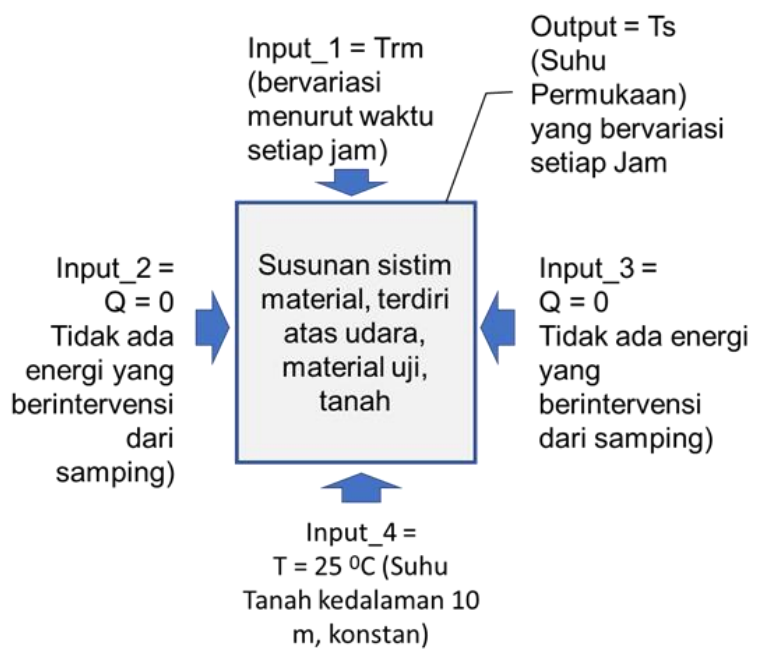

Gambar.4. Pemodelan Input-Boundary layer dan Output untuk simulasi perpindahan panas 2 dimensi menggunakan HEAT2

PAWON: Jurnal Arsitektur, Nomor 02 Volume V, Juli-Desember Tahun 2021, ISSN 2597-7636 
Pada HEAT2, solver yang diterapkan adalah transient calculation, dengan input boundary (pada bagian atas material) berupa angka temperatur yang bervariasi setiap jam, yang merepresentasikan suhu radiasi dari matahari. Gambar.5. menunjukkan interface proses input pada HEAT2. Program komputer RAYMAN (Gambar.6) digunakan sebagai alat bantu untuk menghitung besarnya suhu radiasi rata rata (Trm) karena pengaruh energi radiasi matahari di lingkungan ruang luar, dimana Trm menjadi input boundary pada bagian atas dari sistim material.

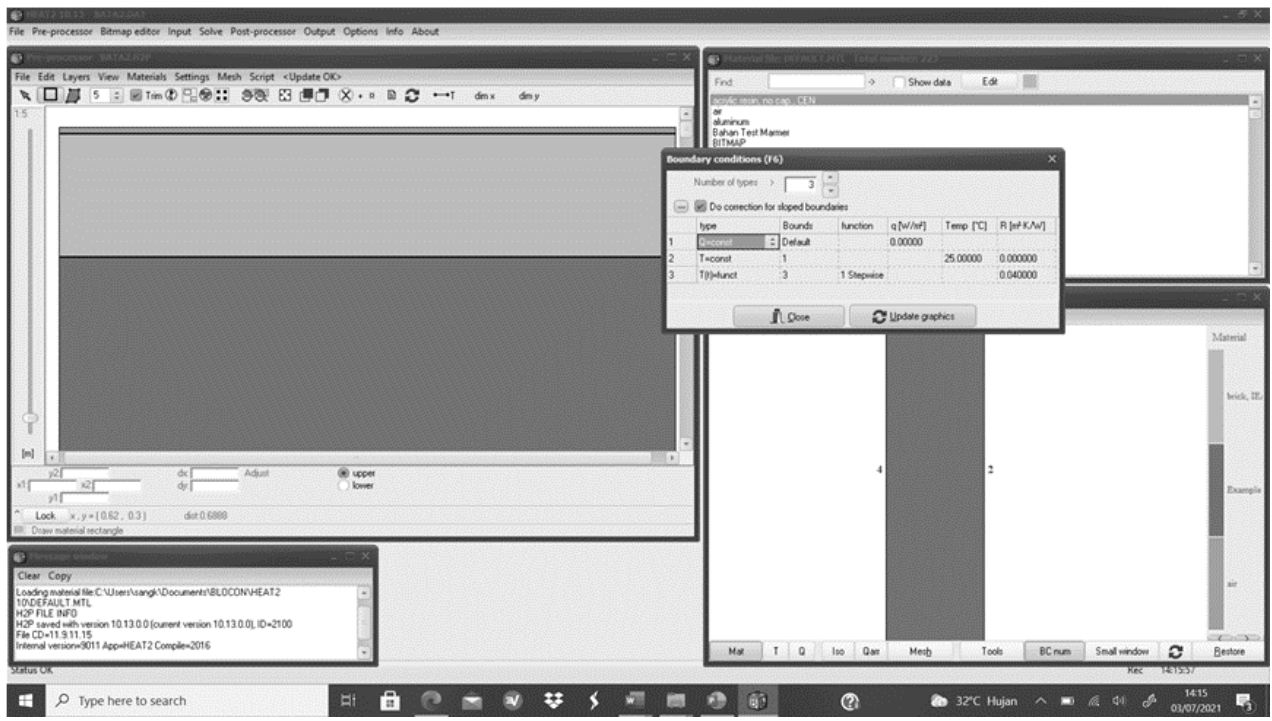

Gambar.5. Tampilan layar (interface) proses input data pada program HEAT2 versi 10.

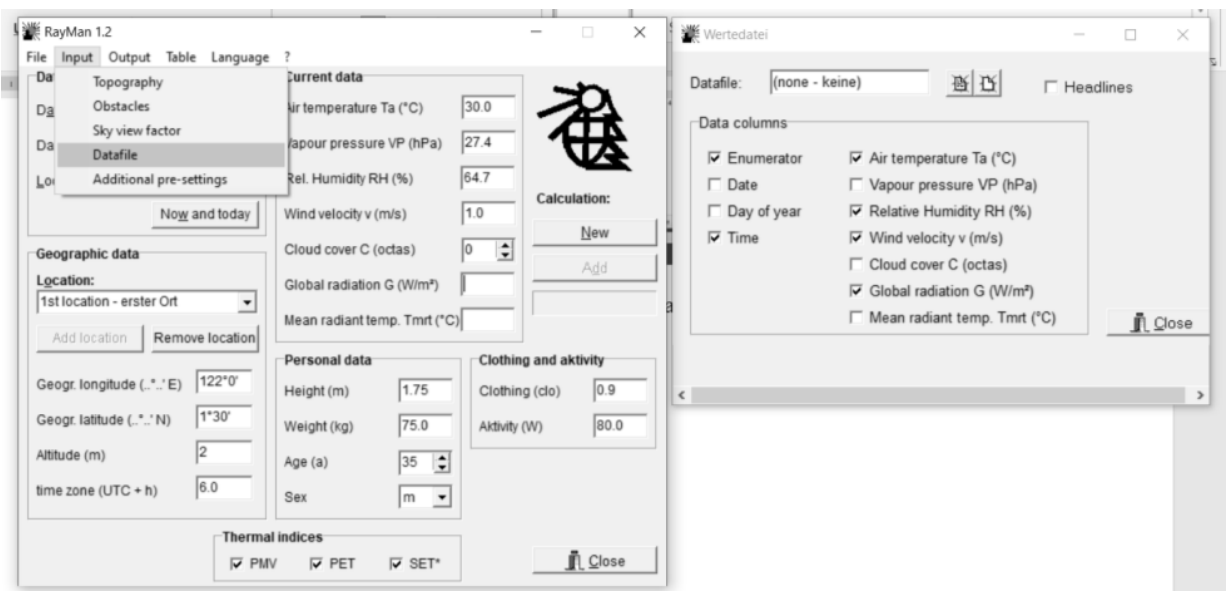

Gambar.6. Proses input data pada program RAYMAN

Perhitungan radiasi matahari dilakukan dengan menggunakan formulasi perhitungan praktis pada umumnya atau yang direkomendasikan 
oleh ASHRAE (Szokolay, 2010), dengan menggunakan spread sheet MSExcel. Suhu tanah bagian dalam ditetapkan konstan $25^{\circ} \mathrm{C}$. Berdasarkan hasil penelitian di daerah tropis, bahwa suhu tanah pada kedalaman $10 \mathrm{~m}$ relatif konstan pada angka $20^{\circ} \mathrm{C}$ (Cui dkk, 2011). Namun studi lainnya oleh Mukhtar dkk, 2017) Menunjukkan angka suhu tanah $28.95^{\circ} \mathrm{C}$ yang juga konstan pada kedalaman $10 \mathrm{~m}$. Karena itu dalam studi ini diambil nilai tengah yaitu $25^{\circ} \mathrm{C}$.

\section{HASIL DAN PEMBAHASAN}

\subsection{Iklim Mikro di Kawasan Pantai Kota Manado}

Hasil pengkuran iklim mikro di kawasan pantai Kota Manado (1.5 LU), yakni di area komersial pantai Mega Mas, pada tanggal 10 Januari Tahun 2020, ditunjukkan pada Gambar 6 dan Tabel.1 Pada situasi menghadap sinar matahari, karena dipengaruhi oleh terik panas matahari maka suhu permukaan bahan lansekap (tanah) hampir mencapai 50 derajat celcius pada saat puncak panas siang hari. Sedangkan apabila berada di bawah naungan pohon yang rindang (jenis pohon Tanjung), maka suhu permukaan bahan tertinggi hanya mendekati 35 derajat Celcius pada pukul 13.00, atau lebih rendah sampai mendekati 30\% dibandingkan apabila menghadap sinar langsung. Suhu permukaan bahan (tanah) dari kedua situasi ini mulai berbeda setelah jam 08.00, dimana pengaruh matahari sudah mulai nampak untuk memperpanas material. Pola perubahan panas, menunjukkan suatu kurva yang memuncak pada saat situasi tengah hari, dan menurun saat pagi dan sore hari. Pola pergerakan suhu permukaan material tersebut menunjukkan tendensi yang sama dengan perubahan besarnya radiasi matahari hasil pengukuran di hari dan jam yang sama. Besarnya radiasi matahari mencapai puncak pada angka hampir menyentuh $1050 \mathrm{~W} / \mathrm{m}^{2}$, pada saat jam 12 siang di titik yang menghadap langit. Sebaliknya di titik yang di naungi pepohonan, angka tertinggi di jam 12 siang, hanya mendekati $150 \mathrm{~W} / \mathrm{m}^{2}$, atau turun drastis sampai sekitar $80 \%$. Para peneliti lain juga menemukan hal yang setara misalnya penelitian di Penang Malaysia, yang terungkap bahwa berkat pepohonan berdaun rapat, maka suhu permukaan tanah dapat tereduksi sampai $17 \%$, dan radiasi matahari dapat tersaring sampai sekitar $80 \%$ (Tukiran, dll, 2016). 

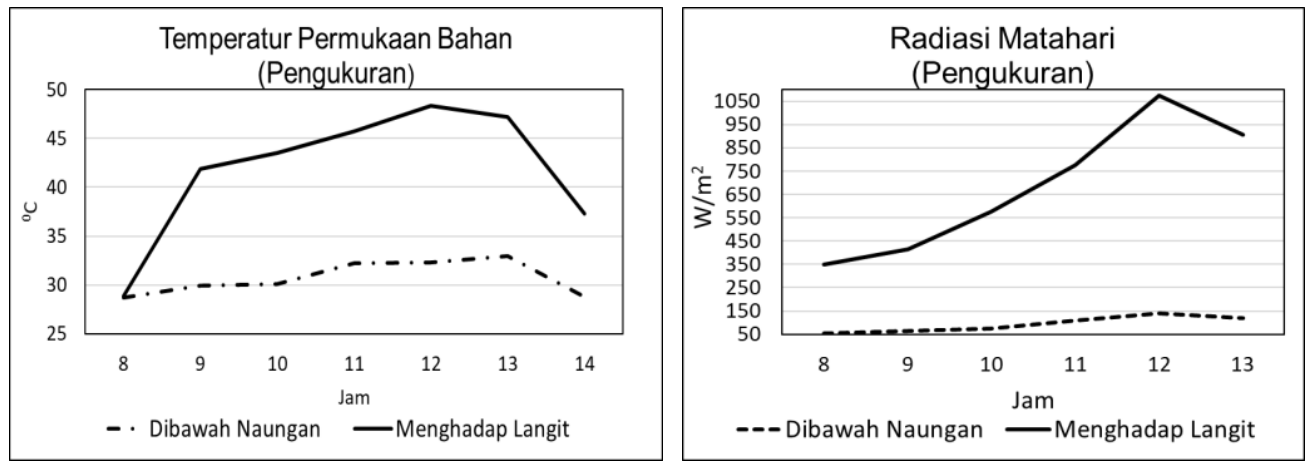

Gambar.6. Hasil pengukuran suhu permukaan bahan dan radiasi matahari

Tabel.1. Hasil Pengukuran suhu dan radiasi matahari.

\begin{tabular}{|c|c|c|c|c|c|}
\hline \multirow{2}{*}{ Jam } & Ta & Ts_1 & Ts_2 & G_1 & G_2 \\
\cline { 2 - 6 } & ${ }^{0} \mathrm{C}$ & ${ }^{0} \mathrm{C}$ & ${ }^{0} \mathrm{C}$ & $\mathrm{W} / \mathrm{m}^{2}$ & $\mathrm{~W} / \mathrm{m}^{2}$ \\
\hline 8 & 29.7 & 28.7 & 28.9 & 54 & 350 \\
\hline 9 & 29.2 & 29.9 & 41.9 & 65 & 416 \\
\hline 10 & 30.9 & 30.1 & 43.5 & 76 & 575 \\
\hline 11 & 30.4 & 32.2 & 45.7 & 109 & 775 \\
\hline 12 & 31.2 & 32.3 & 48.3 & 139 & 1075 \\
\hline 13 & $30 ; 4$ & 33 & 47.2 & 118 & 906 \\
\hline 14 & 28.5 & 28.8 & 37.3 & $\mathrm{NV}$ & $\mathrm{NV}$ \\
\hline
\end{tabular}

Keterangan Ta: suhu udara; Ts_1:suhu permukaan tanah dibawah naungan; Ts_2: suhu permukaan tanah tanpa naungan; G_1: radiasi global (horisontal) di bawah naungan;

G_2:radiasi global (horisontal) tanpa naungan

\subsection{Sifat Termofisis Bahan Lokal}

Hasil pengukuran sifat kapasitas kalor dan konduktifitas termal bahan pavingstone dan batu bata menunjukkan perbedaan dengan angka yang pada umumnya terdapat di sejumlah literatur. Bahan pavingstone buatan lokal, setelah diukur menunjukkan sifat konduktifitas termal dengan nilai yang berbeda cukup jauh dibandingkan yang terdapat di literatur (Tabel.2) Hal ini mungkin disebabkan karena sifat fisika material dasar penyusunnya yang terdiri dari batuan asli atau kerikil yang lebih keras dan padat. Untuk bahan batu bata, hasil pengukuran sifat sifat termofisis, menunjukkan angka yang mendekati atau pada rentang yang umumnya terdapat di literatur. Khusus material seng lokal, tidak dilakukan uji konduktifitas termal. Informasi mengenai data termofisis material dari literatur dapat dilacak di sejumlah situs antara lain di www.enggineeringtoolbox.com, dll. 
Tabel.2. Hasil pengukuran sifat termofisis

\begin{tabular}{l|c|c|c|c|c}
\hline \multirow{2}{*}{ Sifat Termofisis } & \multirow{2}{*}{ Satuan } & \multicolumn{2}{|c|}{ Pavingstone } & \multicolumn{2}{c}{ Bata } \\
\cline { 3 - 6 } & & pengukuran & literatur & pengukuran & literatur \\
\hline Massa Jenis & $\mathrm{kg} / \mathrm{m}^{3}$ & 1947 & $2000-2400$ & 1662 & $1400-2400$ \\
\hline $\begin{array}{l}\text { Kapasitas } \\
\text { Kalor }\end{array}$ & $\mathrm{J} / \mathrm{kg}^{\circ} \mathrm{C}$ & 1423 & $800-1200$ & 1120 & $800-900$ \\
\hline $\begin{array}{l}\text { Konduktifitas } \\
\text { termal }\end{array}$ & $\mathrm{W} / \mathrm{m}^{0} \mathrm{C}$ & 4.1 & $1-2.1$ & 0.9 & $0.6-1$ \\
\hline
\end{tabular}

\subsection{Simulasi Suhu Permukaan Material}

Dalam proses perhitungan menggunakan HEAT2, sebagai input dari boundary di bagian atas sistim material adalah panas radiasi dalam bentuh suhu radiasi karena pengaruh radiasi dan suhu udara. Jadi terlebih dahulu dibuat perhitungan radiasi matahari (mulai saat terbit sampai tenggelam), kemudian menghitung suhu radiasi rata-rata (Trm), yang selanjutnya Trm ini menjadi input pada proses simulasi dengan HEAT2. Konversi dari Radiasi dan Suhu udara menjadi suhu radiasi (Trm) menggunakan program RAYMAN (Gambar7). Hasil perhitungan radiasi matahari dan suhu radiasi rata-rata ditunjukkan pada Gambar.7 dan grafiknya di Gambar. 8. Pada saat radiasi matahari mencapai puncak pada jam 12 siang sebesar $1026 \mathrm{~W} / \mathrm{m}^{2}$, dan suhu udara sebesar $33{ }^{\circ} \mathrm{C}$ maka suhu radiasi rata rata mencapai 63.7 ${ }^{\circ} \mathrm{C}$. Pada saat tidak ada sinar matahari (malam hari), maka suhu radiasi diterapkan sama dengan suhu udara.

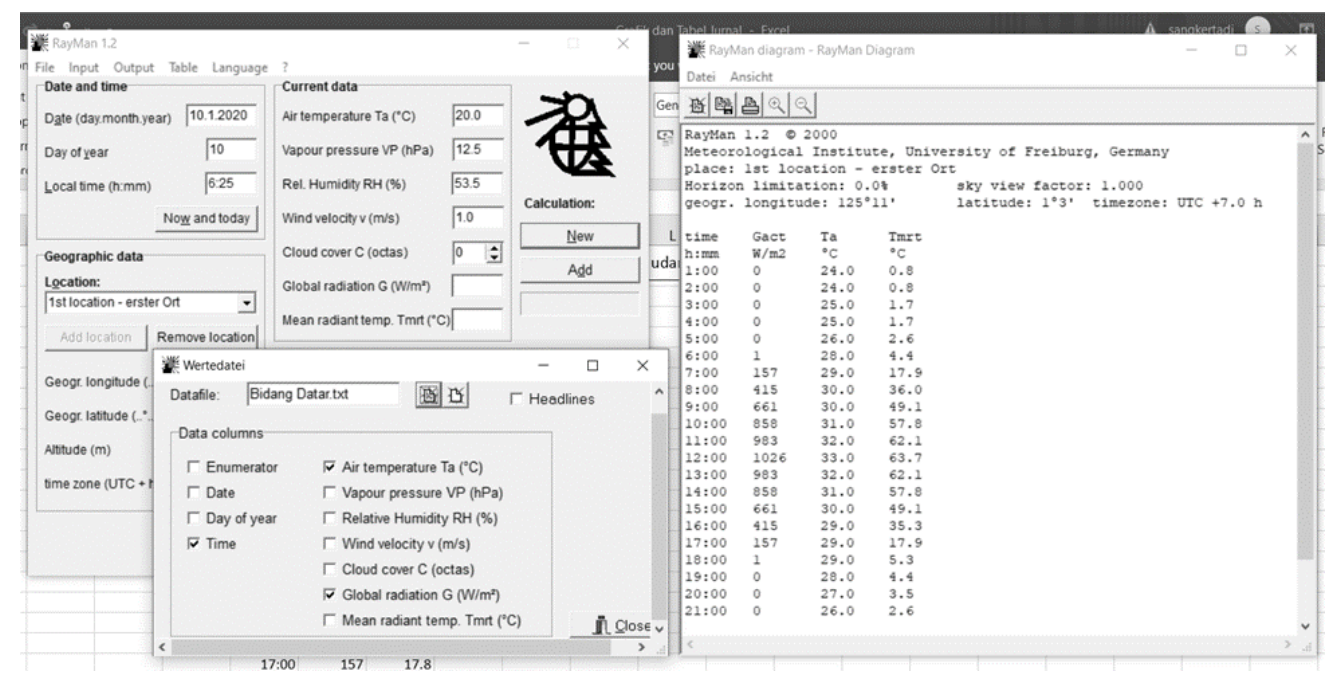

Gambar.7. Tampilan proses input dan output dari Rayman 

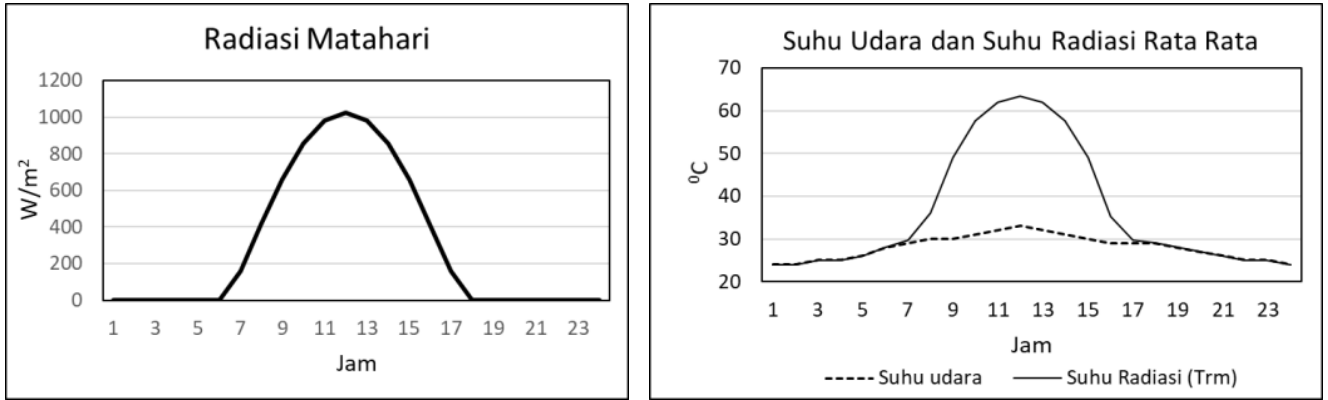

Gambar.8. Radiasi Matahari dan Suhu radiasi rata rata

Proses simulasi komputasional dengan HEAT2, dapat menghasilkan keluaran berupa suhu sejumlah titik di material pada posisi yang dikehendaki, yang dalam hal ini adalah pada titik di permukaan bahan.

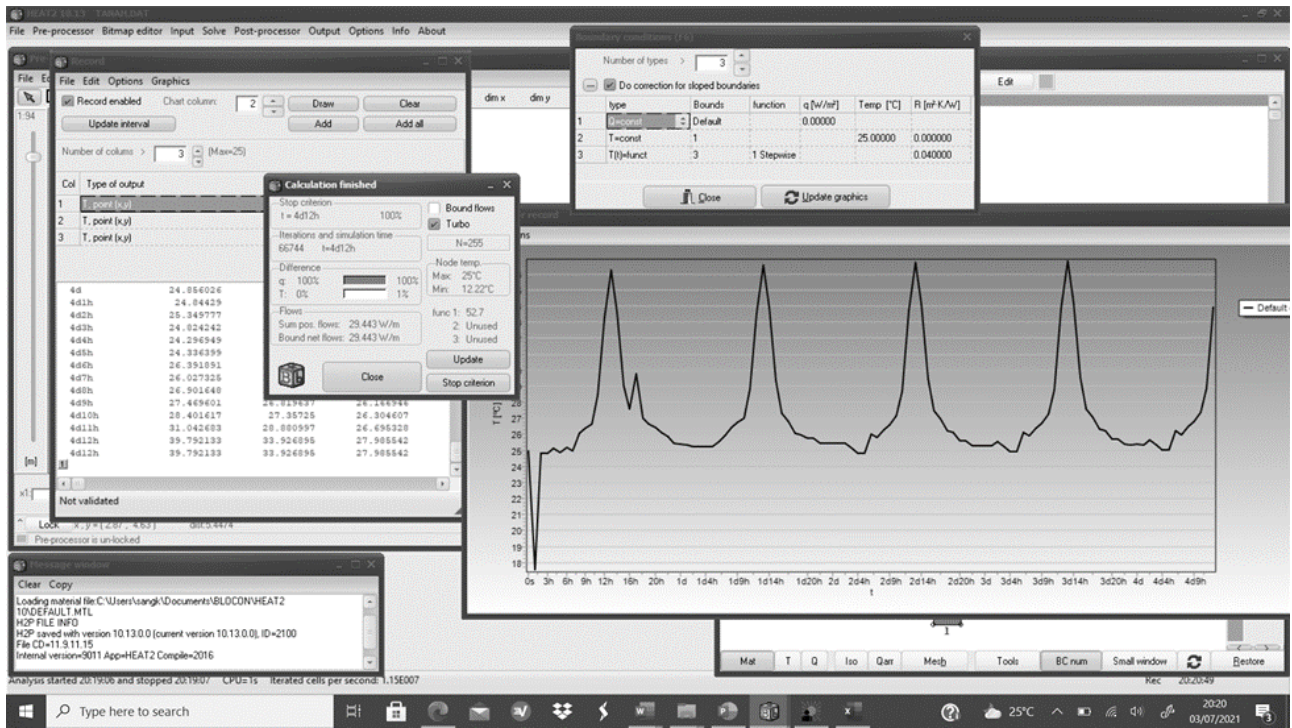

Gambar.9. Proses simulasi dengan HEAT2

Hasil simulasi suhu permukaan bahan dengan menggunakan HEAT2, ditunjukkan pada Gambar 9 dan 10. Suhu permukaan bahan lansekap pavingstone, tanah keras, dan bata, menunjukkan bahwa pada saat tengah hari, suhu tertinggi dapat mencapai pada kisaran antara $45^{\circ} \mathrm{C}$ sampai $50^{\circ} \mathrm{C}$, yang terjadi pada pukul 13 sd 15 . Terjadi kelambatan suhu puncak dibandingkan terhadap saat angka tertinggi panas matahari jam 12. Hal ini disebabkan karena faktor inersia bahan. Faktor kapasitas kalor dan konduktifitas termal bahan, serta proses perpindahan panas ke dalam tanah, juga dapat berkontribusi menyebabkan terjadinya pergeseran waktu puncak panas sampai sekitar 1 sampai 3 jam setelah puncak panas matahari.

PAWON: Jurnal Arsitektur, Nomor 02 Volume V, Juli-Desember Tahun 2021, ISSN 2597-7636 
Kejadian ini juga dikenal sebagai suatu time-lag dari material terhadap beban panas. Sebagai perbandingan bahwa suhu radiasi permukaan material paving mencapai puncak $40{ }^{\circ} \mathrm{C}$ bisa terjadi Jepang, meskipun iklimnya berbeda dengan tropis, sebagaimana di ungkapkan oleh Takebayashi dan Kyogoku (Takebayashi dan Kyogoku, 2018). Jadi jika terjadi suhu puncak sampai mendekati $50{ }^{\circ} \mathrm{C}$ adalah memungkinkan. Dalam hal material air, simulasi suhu badan air menunjukkan karakteristik tertentu, dimana perubahan suhu menurut kedalaman air juga dapat di ketahui melalui perhitungan simulasi. Pada saat dipermukaan, suhu muka air bisa hampir sama dengan suhu benda keras lainnya, yakni mencapai angka puncak tertinggi menyentuh $50^{\circ} \mathrm{C}$. Namun di kedalaman $20 \mathrm{~cm}$ suhu puncak sudah menurun jauh hingga sekitar $25^{\circ} \mathrm{C}$, Bahkan pada kedalaman $50 \mathrm{~cm}$, suhu air relatif stabil pada angka sekitar $25^{\circ} \mathrm{C}$, pada periode jam 7.00 sampai 17.00. Dengan demikian, air pada kedalaman $50 \mathrm{~cm}$, apabila dicampurkan dengan air permukaan, maka akan ada kecenderungan pnurunan suhu air secara menyeluruh, dimana situasi percampuran ini akan berpotensi menurunkan suhu lingkungan iklim mikro.
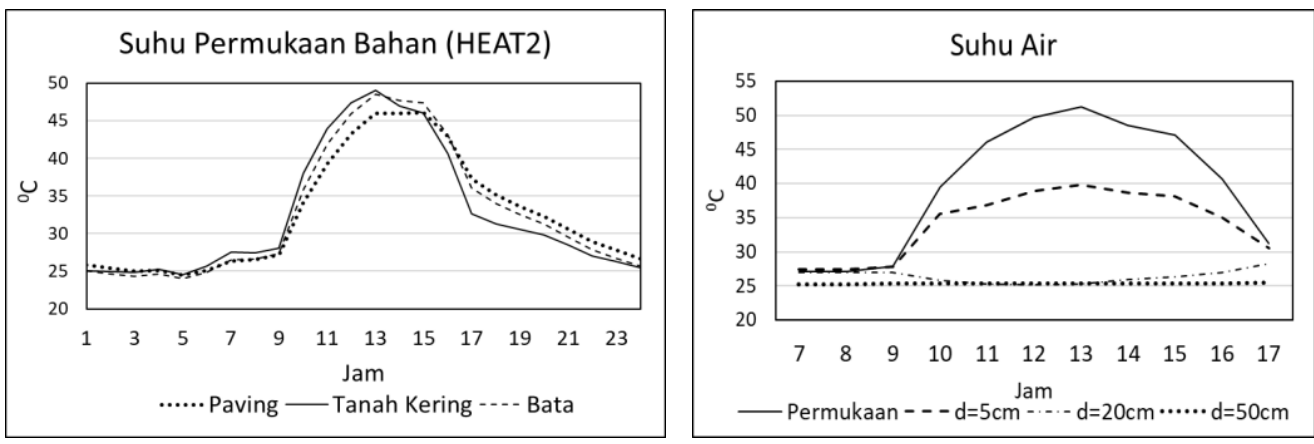

Gambar.10.Hasil simulasi dengan HEAT2 untuk suhu material padat dan air

Hasil perbandingan antara pengukuran dan simulasi, ditunjukkan pada Tabel.3, dimana tidak terjadi perbedaan yang terlalu jauh, baik untuk kasus air, maupun material padat. Ini menunjukkan validitas dari hasil simulasi komputasional yang didapatkan pada studi ini. 
Tabel.3. Perbandingan suhu air dan permukaan bahan $\left({ }^{\circ} \mathrm{C}\right)$

\begin{tabular}{|c|c|c|c|c|c|c|}
\hline \multirow{2}{*}{ Waktu } & \multicolumn{2}{|c|}{$\begin{array}{l}\text { Air (kedalaman } \\
1 \mathrm{~cm})\end{array}$} & \multicolumn{2}{|c|}{ Paving } & \multicolumn{2}{|c|}{ Tanah kering } \\
\hline & ukur & simulasi & ukur & simulasi & ukur & simulasi \\
\hline 10 & 33.2 & 36.55 & - & - & 39.3 & 38.09 \\
\hline 11 & 38.4 & 41.54 & 45.7 & 39.31 & 40.1 & 43.96 \\
\hline 12 & 38.8 & 44.4 & 48.3 & 43.29 & 45.1 & 47.43 \\
\hline 13 & - & - & 47.2 & 46.01 & 43 & 49.08 \\
\hline
\end{tabular}

\section{KESIMPULAN}

Sebagai kesimpulan melalui studi ini dapat dinyatakan sebagai berikut:

a) Sifat termofisis bahan lansekap, mempengaruhi kuantitas iklim mikro sekitarnya, khususnya komponen suhu radiasi lingkungan yang disebabkan oleh suhu permukaan material tersebut. Sifat kapasitas kalor dan konduktifitas termal, juga menyebabkan pergeseran waktu suhu puncak lingkungan iklim mikro, dibandingkan dengan saat puncak terbesar radiasi matahari.

b) Faktor vegetasi berupa pepohonan berdaun rapat sangat berpotensi mereduksi atau menyaring radiasi matahari dibawahnya, hingga bisa mencapai $80 \%$ saat tengah hari, dikarenakan adanya penaungan atau pembayangan yang sangat efektif. Selain itu, pohon berdaun rapat juga dapat mereduksi suhu permukaan material di bawah penaungannya hingga 30\%, saat matahari tegak vertikal diatasnya.

c) Hasil simulasi komputasi, menunjukkan bahwa suhu permukaan bahan bahan perkerasan yakni pavingstone, bata dan tanah keras, saat siang hari dapat mencapai mendekati $50{ }^{\circ} \mathrm{C}$ saat tengah hari, cuaca cerah, tegak menghadap langit. Sedangkan suhu air juga berpotensi menjadi pendingin lingkungan, apabila diadakan peradukan antara suhu air di kedalaman lebih dari $20 \mathrm{~cm}$ dengan suhu permukaan, sehingga terjadi suhu campuran yang lebih dingin dibandingkan suhu permukaan. Perbandingan antara hasil pengukuran dan simulasi tidak menunjukkan perbedaan yang signifikan, sehingga dapat dinyatakan valid terhadap proses perhitungan dengan cara simulasi komputasional.

Temuan tersebut memberi masukan yang konstruktif bagi pengembangan desain arsitektur lansekap khususnya di dareah beriklim tropis, dalam rangka memberikan rasa kenyamanan berkegiatan di ruang luar 


\section{DAFTAR PUSTAKA}

ASHRAE, 2017. ASHRAE Handbook Fundamentals. Atlanta: American Society of Heating, Refrigerating and Air-Conditioning Engineers (ASHRAE) Inc.

Choi GY, Kim AH, Kim H, Lee JS, 2021, How do paving and planting strategies affect microclimate conditions and thermal comfort in apartment complexes? , International Journal of Climate Change Strategies and Management, Vol. 13 No. 2, 2021

Cui W, Liao Q, Chang G, Chen G, Peng Q and Jen TC. Measurement and prediction of undisturbed underground temperature distribution. In: Proceedings of the ASME 2 international mechanical engineering congress \& exposition, IMECE2011, Denver, CO, USA, January 1 2011.

Gaitani N, Spanou A, Saliari M, Synnefa A, Vassilakopoulou K, Papadopoulou K, Pavlou K, Santamouris M, Papaioannou M, Lagoudaki A, 2011, Improving themicroclimate inurbanareas: acasestudy in the centre of Athens, Building Serv. Eng. Res. Technol. Vol 32, No. 1, 2011.

Givoni B, 1998, Climate Considerations in Building and Urban Design, New Yoyrk: John Wiley \& Sons.

lek Y, Sangkertadi, Moniaga I, 2014, Kepadatan Bangunan dan Karakteristik Iklim Mikro Kecamatan Weang Kota Manado. Jurnal Sabua Vol,6 No.3.

Joo-Hwa B and Lay OB. 2006. Tropical Sustainable Architecture. Social and Environmental Dimensions. London:Architectural Press

Karyati, 2019. Mikroklimatologi Hutan, Samarinda: Mulawarman University Press.

Lakitan B, 2002. Dasar-dasar Klimatologi, Jakarta: Raja Grafindo Persada.

Lesi M, 2017. Iklim Mikro di Sekitar Permukaan Air. Pascasarjana Institut Pertanian Bogor.

Mukhtar A, Yusoff MY, Ching NK, 2017, An Empirical Estimation of Underground Thermal Performance for Malaysian Climate, IOP Conf. Series: Journal of Physics: Conf. Series 949 (2017).

Noerwasito T V, 2020, Blok Tanah Liat Untuk Arsitektur, K-Media, Yogyakarta.

Sangkertadi, 2013, Kenyamanan Termal di Ruang Luar Beriklim Tropis Lembab, Bandung: Alfabeta.

Sangkertadi \& Syafriny R, 2016, Pair influence of wind speed and mean radiant temperature on outdoor thermal comfort of humid tropical 
environment, Journal of Urban and Environmental Engineering, Vol.10 No.2, 2016

Shahidan F M, Salleh E, Mustafa KMS, 2007. Effects of tree canopies on solar radiation filtration in a tropical microclimatic environment. The 24th Conference on Passive and Low Energy Architecture, Singapore, 22-24 November 2007.

Szokolay S V. 2010. Introduction to Architectural Science: The Basis of Sustainable Design. Oxford: Architectural Press

Takebayashi H dan Kyogoku S. 2018. Thermal Environmental Design in Outdoor Space Focusing on Radiation Environment Influenced by Ground Cover Material and Solar Shading, through the Examination on the Redevelopment Buildings in Front of Central Osaka Station. Japan. MDPI Sustainability Jurnal, 2018.

Thani S.K.S.O, dkk. 2013. Outdoor thermal comfort: the effects of urban landscape morphology on microclimatic conditions in a hot-humid city". WIT Transactions on Ecology and The Environment, Vol 179, 2013.

Tukiran J Md, Ariffin J, Abdul Ghani, AN, 2016, Cooling Effects of Two Typess of Tree Canopy Shape in Penang Malaysia, International Journal of GEOMATE, Vol. 11, Issue 24.

Yang W, Lin Y, Li CQ, 2018. Effects of Landscape Design on Urban Microclimate and Thermal Comfort in Tropical Climate. Hindawi Advances in Meteorology Vol.2018, Article ID 2809649.

Zold, A. and Szokolay S,1997. Thermal Insulation. PLEA Note 2. PLEA University of Queensland. 